\title{
Optimized production of tannase and gallic acid from fruit seeds by solid state fermentation
}

\author{
Rida Arshad ${ }^{1}$, Ayesha Mohyuddin ${ }^{1 *}$, Shagufta Saeed ${ }^{2}$, Abrar UI Hassan $^{1}$ \\ ${ }^{1}$ Department of Chemistry, School of Science, University of Management and Technology, ${ }^{2}$ Institute of Biochemistry and \\ Biotechnology, University of Veterinary and Animal Science, Lahore, Pakistan
}

*For correspondence: Email: ayesha.mohyuddin@umt.edu.pk; Tel: +92-301-4324884

\begin{abstract}
Purpose: To investigate the possibility for gallic acid production from different tannin-rich fruit seeds using Aspergillus oryzae via solid-state fermentation.

Methods: Fruit seeds of apple, guava, tamarind, black plum and watermelon were analyzed to estimate the synthesis of an enzyme tannase and its product gallic acid. Various physicochemical parameters were optimized to increase the gallic acid yield. Gallic acid was extracted by Soxhlet apparatus and identified by Fourier-transform infrared spectroscopy (FTIR). It was quantitatively determined by high performance liquid chromatography (HPLC).

Results: Amongst the various substrates tested, black plum seeds gave the highest activity of 34.40 $\mathrm{U} / \mathrm{g}$ for tannase and $16.66 \mathrm{mg} / \mathrm{g}$ for gallic acid under optimized physicochemical conditions, i.e., 1:3 substrate: moisture ratio, $30{ }^{\circ} \mathrm{C}, 96 \mathrm{~h}$ incubation period and $\mathrm{pH}$ 5.5. Addition of carbon source had a negative effect on production while ammonium sulphate $(0.2 \%)$ as nitrogen source increased the yield of both products. The gallic acid produced was $98.5 \%$ pure, compared to the standard.

Conclusion: Production of tannase and gallic acid via solid-state fermentation conditions has been optimized in vitro. The optimized conditions can be utilized on a commercial scale for economically viable production of gallic acid.
\end{abstract}

Keywords: Tannin rich seeds, Solid-state fermentation, Tannase, Gallic acid, Aspergillus oryzae

\begin{abstract}
This is an Open Access article that uses a fund-ing model which does not charge readers or their institutions for access and distributed under the terms of the Creative Commons Attribution License (http://creativecommons.org/licenses/by/4.0) and the Budapest Open Access Initiative (http://www.budapestopenaccessinitiative.org/read), which permit unrestricted use, distribution, and reproduction in any medium, provided the original work is properly credited.

Tropical Journal of Pharmaceutical Research is indexed by Science Citation Index (SciSearch), Scopus, International Pharmaceutical Abstract, Chemical Abstracts, Embase, Index Copernicus, EBSCO, African Index Medicus, JournalSeek, Journal Citation Reports/Science Edition, Directory of Open Access Journals (DOAJ), African Journal Online, Bioline International, Open-J-Gate and Pharmacy Abstracts
\end{abstract}

\section{INTRODUCTION}

Tannase, which is also called tannin acyl hydrolase E.C. 3.1.1.20, is a hydrolytic, inducible enzyme that can be synthesized during fermentation. Tannase cleaves the ester bonds present in hydrolyzable tannins in order to release the desired product gallic acid. It has been reported that some microorganisms use tannins as substrates for growth and produce tannase and other products of industrial importance [1]. Tannase has many applications in pharmaceutical and beverage industries. It is employed for the clarification of wines, flavored soft drinks, coffee and for flavoring in food. It helps in de-esterification of tea polyphenols in 
green tea leaves [2].

Gallic acid is an organic compound with chemical formula $\mathrm{C}_{6} \mathrm{H}_{2}(\mathrm{OH})_{3} \mathrm{COOH}$. Gallates are the salts or esters of gallic acid. Gallic acid, in its pure form, is colorless and exist in crystalline form with melting point $250{ }^{\circ} \mathrm{C}$ and molar mass 17.12 $\mathrm{g} / \mathrm{mol}$ [3]. Gallic acid has wide range of applications in different industries from health and food to dyes, inks, paints and photography [4]. It is utilized for the treatment of allergic diseases such as allergic rhinitis, asthma, sinusitis by inhibiting histamine discharge, and expression of pro inflammatory cytokine. Its antimicrobial action is also reported against human and plant pathogens. In food industry, it is utilized as food preservative and antioxidant in the form of pyrogallol and gallates [5]. Its cytotoxic potential has been analyzed against cancer cells. Gallic acid has also been used for the treatment of albuminuria and diabetes. Having antifungal and antiviral properties, gallic acid is reported to reduce the oxidative damage of human cells [6].

The high demand of tannase enzyme and its hydrolyzed product gallic acid is due to to their utilization in medicine, chemical, and food industries. The yearly demand of gallic acid is almost 8000 tonnes [5]. Tannins are present in different parts of the plants like bark, leaves, seeds and flowers [7]. Acid hydrolysis of tannins is commercially employed to obtain gallic acid. The method needs replacement due to low yield and less purity of gallic acid produced. An alternative way to produce gallic acid is by microbial fermentation. Different microbes have ability to produce tannase that can hydrolyze tannic acid to produce gallic acid. However, for fermentation, pure tannic acid is used as substrate that makes the overall process expensive. Due to increasing demand of gallic acid, there is a need to diversify the substrate and identify the hyperproducer microorganism to obtain high yield of gallic acid. Increase in population and industries have resulted in generation of large amount of solid waste. Almost more than $30 \%$ waste comes from food and agriculture sources which are usually dumped in water and land [8]. This waste can be used to generate useful products like gallic acid.

Hence, the present study is designed to explore the potential of various indigenous fruit seeds, usually thrown away as waste, to be the alternate substrates for the production of tannase and gallic acid via solid state fermentation using a fungal isolate Aspergillus oryzae (A. oryzae).

\section{EXPERIMENTAL}

\section{Collection of substrate}

Seeds of apple (Malus pomila), black plum (Syzygium cumini), watermelon (Citrullus vulgaris), tamarind (Tamarindus indica) and guava (Psidium guajava) were collected from local markets, dried in oven till moisture free and then powdered by using grinder. The powder was sieved through a mesh to obtain the particles having size up to $50 \mu \mathrm{m}$ and it was then used as substrate for fermentation studies [6].

\section{Evaluation of tannic acid content of substrate}

Fruit seeds powder $(5 \mathrm{~g})$ was mixed in $10 \mathrm{~mL}$ of $70 \%$ methanol and kept at $4{ }^{\circ} \mathrm{C}$ for 12 hours. Extract of fruit seeds $(1 \mathrm{~mL})$ was mixed with bovine serum albumin solution $(3 \mathrm{~mL})$ and left to stand at room temperature for $15 \mathrm{~min}$. Seed pellets were obtained by centrifugation of these extracts at $5000 \mathrm{rpm}$ for $10 \mathrm{~min}$. The supernatant was discarded and pellets were dissolved in a solution of SDS-triethanolamine $(3 \mathrm{~mL})$. It was mixed with $\mathrm{FeCl}_{3}$ solution $(1 \mathrm{~mL})$ and incubated at room temperature for $15 \mathrm{~min}$. The absorbance for both standard and sample was taken in reference to blank at $520 \mathrm{~nm}$ [9].

\section{Preparation of inoculum}

The characterized strain of $A$. oryzae (FCBPPTF-1202) was procured from $1^{\text {st }}$ cultural fungal bank of Pakistan, Institute of Agricultural Sciences, University of the Punjab, Lahore. Sabouraud dextrose agar slant was used to maintain the fungal strain at $4{ }^{\circ} \mathrm{C}$ [2]. Sporulated culture of $A$. oryzae was taken and mixed thoroughly in properly sterilized $0.9 \% \mathrm{NaCl}$ solution. The spore suspension was further diluted at concentration of $2 \times 10^{7}$ spores $/ \mathrm{mL}$ to be used as inoculum [1].

\section{Selection of substrate for gallic acid and tannase production}

Five grams of each substrate was taken in different $250 \mathrm{~mL}$ flasks and moisturized by adding basal media at the substrate : water ratio $(w / v)$ of $1: 6$. The basal medium contained salts required for the fungal growth with the composition dipotassium hydrogen phosphate $(1.0 \mathrm{~g})$, magnesium sulfate $(0.5 \mathrm{~g})$, sodium nitrate $(3.0 \mathrm{~g})$, potassium chloride $(0.5 \mathrm{~g})$. The salts were dissolved in 1 liter of distilled water and $\mathrm{pH}$ was set at 6.5. After the addition of basal media, the flasks were subjected to autoclave for $15 \mathrm{~min}$ at $121{ }^{\circ} \mathrm{C}$ and then inoculum $(1 \mathrm{~mL})$ was added to start the fermentation. The fermentation was 
carried out by incubation at $30{ }^{\circ} \mathrm{C}$ for 72 hours. Finally, after 3 days, the gallic acid and tannase produced in each flask were estimated. The substrate giving highest yield of the products was selected for further optimization studies [7].

\section{Hyperproduction of tannase and gallic acid by optimization of physicochemical conditions}

After selection of best substrate for synthesis of tannase and gallic acid, various physical and chemical parameters were optimized to achieve the better yield of gallic acid and tannase. Firstly, substrate : water ratio was optimized by mixing the substrate and basal media in different proportions, i.e., 1:1 - 1:6 (w/v) [10]. The flasks were autoclaved and inoculated with microorganism by using the procedure described in previous section. After optimization of substrate : water ratio, the fermentation was carried out at different time intervals in the range of 24 to $120 \mathrm{~h}$ with a difference of $24 \mathrm{~h}$ for the selection of best time duration [11]. The best suitable $\mathrm{pH}$ level was selected by increasing the $\mathrm{pH}$ from 4.5-8.5 with a difference of 1.0. The fermentation was carried out at different temperatures ranging from 20 to $70{ }^{\circ} \mathrm{C}$ by using previously optimized conditions for the selection of optimum temperature [12]. The effect of addition of carbon and nitrogen source in fermentation media was also tested for tannase and gallic acid production. Sucrose, glucose, fructose and starch solution (0.2\%) were used as carbon source and ammonium sulphate, urea, peptone, and yeast extract $(0.2 \%)$ were used as nitrogen source. "Changing one variable at a time" approach was used for optimization [13].

\section{Evaluation of tannase activity and gallic acid}

Spectrophotometric method was used to determine the tannase activity and gallic acid content by using rhodanine on spectronic-21 spectrophotometer [14]. Tannase concentration is estimated by chromogen formation between rhodanine and gallic acid which shows maximum absorbance at $520 \mathrm{~nm}$. The standards of tannase and gallic acid (Sigma-Aldrich) were used to determine the yield of products.

\section{Crystallization of gallic acid}

Fermented sample (10 g) was placed in a thimble with $300 \mathrm{~mL}$ of $70 \%$ ethanol (solvent) and extracted in soxhlet apparatus. Extraction was carried out for $6 \mathrm{~h}$. The filtered extract was concentrated at $50^{\circ} \mathrm{C}$ by using rotary evaporator [15].

\section{Identification and quantitative determination of gallic acid}

Identification of gallic acid was carried out by scanning the sample against standard using FTIR (Shimadzu/ Prestige-21). Quantitative estimation and purity of gallic acid produced was determined by HPLC [3]. HPLC instrument of Agilent Technologies (1260 infinity) having DAD detector was used in the study. Mobile phase contained a mixture of methanol-water ( $\mathrm{v} / \mathrm{v}$ ratio, $1: 9)$, and $0.02 \%$ trifluoroacetic acid. The flow rate of mobile phase was adjusted at $0.5 \mathrm{~mL} / \mathrm{min}$. Eclipse plus C18 column (4.6 x 100mm, $3.5 \mu)$ was used to analyze the Standard (gallic acid $1 \mathrm{mg} / \mathrm{mL}$ ) and fermented filtrate (sample) with injection volume $10 \mu \mathrm{L}$. The chromatograms were recorded at $245 \mathrm{~nm}$.

\section{Statistical analysis}

All the experiments were run in triplicate. The data were analyzed by using SPSS 16 software and reported as mean \pm standard deviation. Mean of the triplicate experiments were compared by one way ANOVA, descriptive analysis and least significant difference. The results were considered significant at $p<0.05$ [10].

\section{RESULTS}

\section{Tannin content}

Black plum seeds showed highest tannin content (191.25 mg/g dry seeds) and then tamarind (129.5 mg/g dry seeds), guava $(1.25 \mathrm{mg} / \mathrm{g}$ dry seeds), apple (0.205 $\mathrm{mg} / \mathrm{g}$ dry seeds), and watermelon $(0.11 \mathrm{mg} / \mathrm{g}$ dry seeds).

\section{Best substrate for synthesis of gallic acid and tannase}

Black plum seeds demonstrated highest tannase activity $(20.12 \mathrm{U} / \mathrm{g})$ followed by tamarind seeds (5.998 U/g), Guava seeds (1.894 U/g), apple seeds $(1.367 \mathrm{U} / \mathrm{g})$ and watermelon seeds (1.256 $\mathrm{U} / \mathrm{g})$.

Similar trend was also found in gallic acid production. Black plum seeds shows highest yield of gallic acid $(8.16 \mathrm{mg} / \mathrm{g})$ followed by tamarind seeds (1.702 $\mathrm{mg} / \mathrm{g})$, guava seeds (0.742 $\mathrm{mg} / \mathrm{g})$, apple seeds $(0.406 \mathrm{mg} / \mathrm{g})$ and water melon seeds $(0.321 \mathrm{mg} / \mathrm{g})$ as shown in Figure 1. 


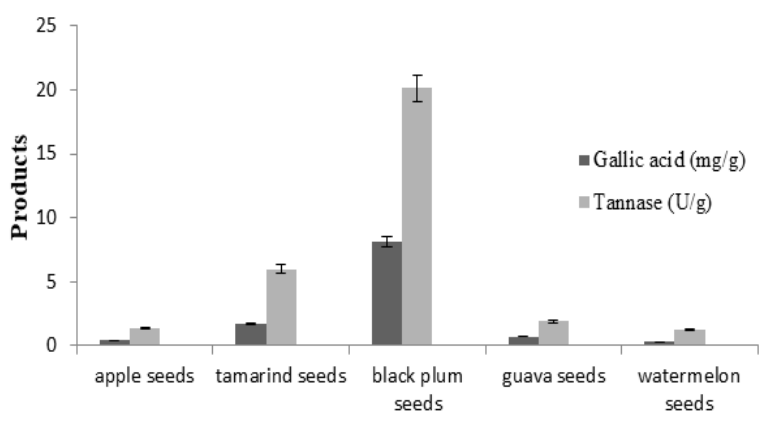

Figure 1: Selection of best substrate for gallic acid and tannase synthesis

\section{Optimized physicochemical conditions for hyperproduction of products}

Different optimized parameters were applied for increasing the tannase and gallic acid production.

\section{Substrate-water ratio}

For the selection of optimum substrate : water ratio, best gallic acid and tannase producing substrate (black plum seed), and basal media were mixed in different ratios $(\mathrm{w} / \mathrm{v}) 1: 1$ to $1: 6$. The 1:3 ratio showed highest tannase and gallic acid production $(23.44 \mathrm{U} / \mathrm{g}), \quad(14.43 \mathrm{mg} / \mathrm{g})$ followed by $1: 1(19.63 \mathrm{U} / \mathrm{g}),(10.56 \mathrm{mg} / \mathrm{g}) 1: 2$ $(22.96 \mathrm{U} / \mathrm{g}),(13.57 \mathrm{mg} / \mathrm{g}), 1: 4(23.01 \mathrm{U} / \mathrm{g})$, $(14.33 \mathrm{mg} / \mathrm{g}), 1: 5(21.33 \mathrm{U} / \mathrm{g}),(13.06 \mathrm{mg} / \mathrm{g})$, and $1: 6(20.12 \mathrm{U} / \mathrm{g}),(8.16 \mathrm{mg} / \mathrm{g})$ as shown in Figure 2.

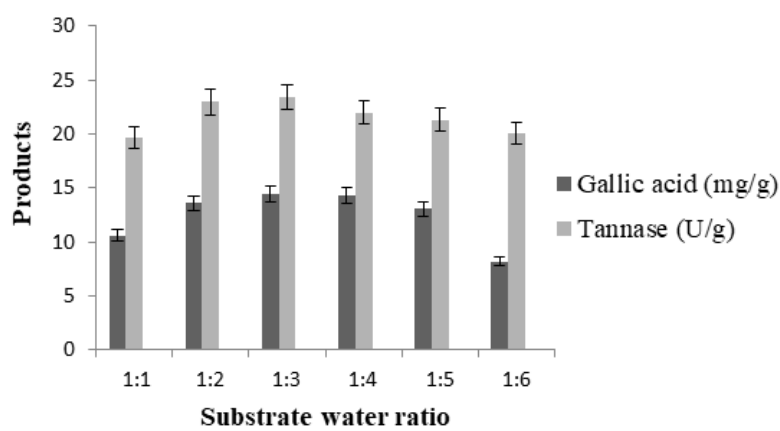

Figure 2: Optimization of Substrate : water ratio for gallic acid and tannase production by black plum seeds

\section{Incubation period}

The incubation period of 96 hours for the fermentation was found to achieve the best production of tannase $(26.40 \mathrm{U} / \mathrm{g})$ as well as of gallic acid $(15.01 \mathrm{mg} / \mathrm{g})$. These were followed by $72 \mathrm{~h}(24.49 \mathrm{U} / \mathrm{g}),(14.45 \mathrm{mg} / \mathrm{g}), 48 \mathrm{~h}(23.44 \mathrm{U} / \mathrm{g})$, $(12.11 \mathrm{mg} / \mathrm{g})$ and $24 \mathrm{~h}(12.26 \mathrm{U} / \mathrm{g}),(5.3 \mathrm{mg} / \mathrm{g})$. On further increase in incubation time to $120 \mathrm{~h}$ the yield of tannase $(21.53 \mathrm{U} / \mathrm{g})$ and gallic acid $(12.35 \mathrm{mg} / \mathrm{g})$ decreased as shown in Figure 3.

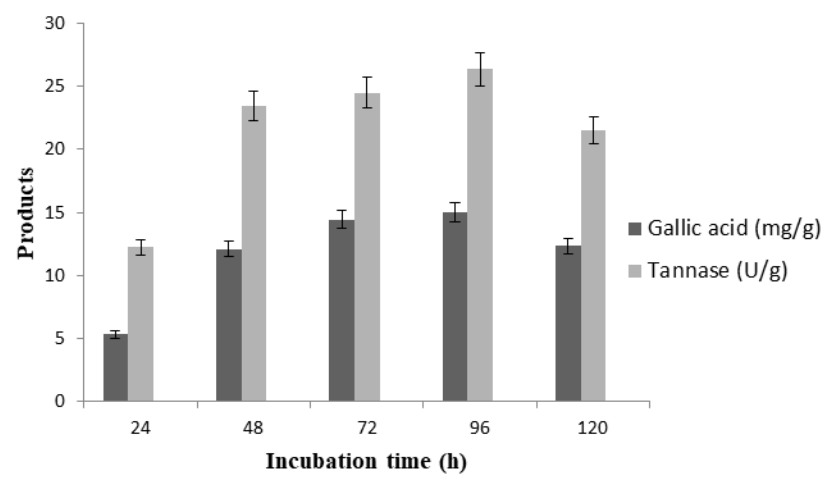

Figure 3: Production of Gallic acid and Tannase after different incubation periods

\section{Effect of $\mathrm{pH}$}

Solid state fermentation for the production of gallic acid and tannase was carried out by varying $\mathrm{pH}$ of basal media from 4.5-8.5. The yields of tannase $(30.01 \mathrm{U} / \mathrm{g})$ as well as gallic acid $(16.00 \mathrm{mg} / \mathrm{g})$ were found to be maximum when $\mathrm{pH}$ was kept at 5.5 , followed by $\mathrm{pH} 6.5$ $(26.40 \mathrm{U} / \mathrm{g})$, (15.01 mg/g); pH $4.5(24.24 \mathrm{U} / \mathrm{g})$, $(12.86 \mathrm{mg} / \mathrm{g})$ and $\mathrm{pH} 7.5(22.18 \mathrm{U} / \mathrm{g}),(11.92$ $\mathrm{mg} / \mathrm{g})$. The lowest yield of the products $(20.94$ $\mathrm{U} / \mathrm{g}), \quad(10.24 \mathrm{mg} / \mathrm{g})$ was observed at $\mathrm{pH} 8.5$ (Figure 4).

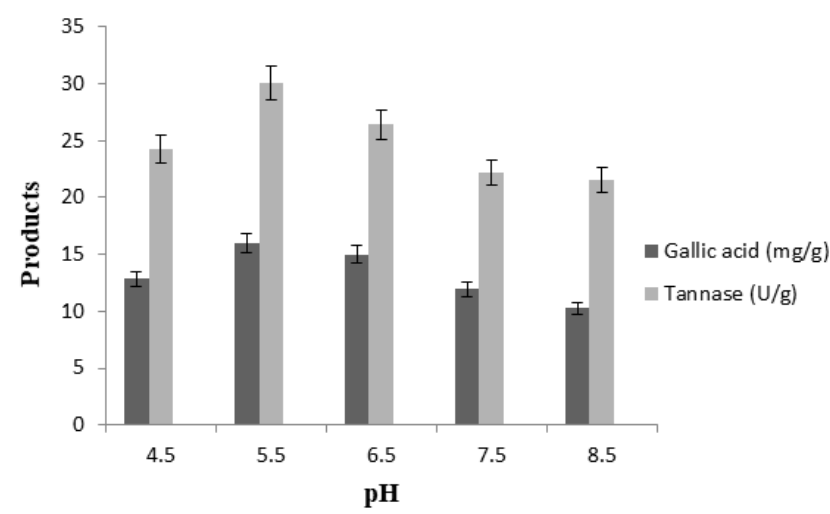

Figure 4: Production of gallic acid and tannase at different initial $\mathrm{pH}$ of basal media

\section{Incubation temperature}

The production of tannase $(\mathrm{U} / \mathrm{g})$ and gallic acid $(\mathrm{mg} / \mathrm{g})$ by solid state fermentation was maximum $(30.01 \mathrm{U} / \mathrm{g})$ and $(16.00 \mathrm{mg} / \mathrm{g})$ when incubation temperature was $30^{\circ} \mathrm{C}$. It was followed by $40^{\circ} \mathrm{C}$ $(24.82 \mathrm{U} / \mathrm{g}),(13.83 \mathrm{mg} / \mathrm{g}) ; 50{ }^{\circ} \mathrm{C}(23.26 \mathrm{U} / \mathrm{g})$, $(13.63 \mathrm{mg} / \mathrm{g}) ; 60{ }^{\circ} \mathrm{C}(21.53 \mathrm{U} / \mathrm{g}),(13.20 \mathrm{mg} / \mathrm{g})$; and the lowest at $70^{\circ} \mathrm{C}(20.64 \mathrm{U} / \mathrm{g}),(12.40 \mathrm{mg} / \mathrm{g})$ as shown in Figure 5. 


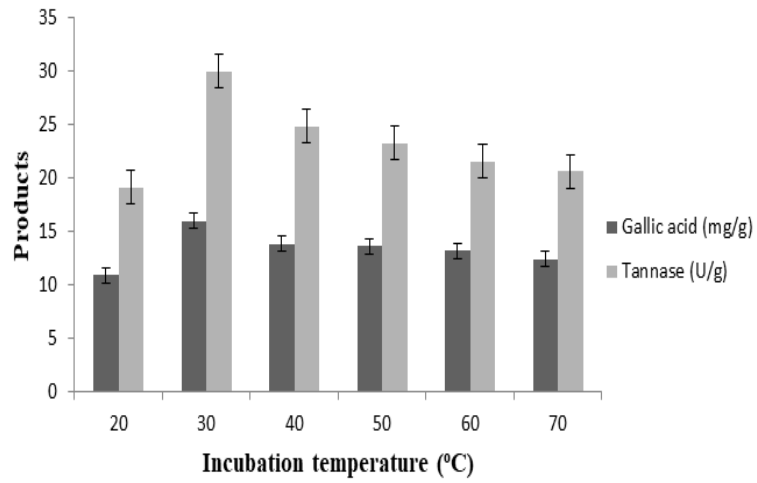

Figure 5: Production of gallic acid and tannase at different incubation temperatures by black plum seeds via solid-state fermentation

\section{Carbon source}

The negative effect on the synthesis of tannase and gallic acid was observed when different carbon sources were added in the fermentation media. Concentrations obtained for tannase and gallic acid produced in control were $30.01 \mathrm{U} / \mathrm{g}$ and $16.00 \mathrm{mg} / \mathrm{g}$ respectively while sharp decrease in production was observed by addition of glucose $(28.00 \mathrm{U} / \mathrm{g}$ and $15 \mathrm{mg} / \mathrm{g})$, fructose $(25.84 \mathrm{U} / \mathrm{g}$ and $12.32 \mathrm{mg} / \mathrm{g})$, sucrose $(19.62 \mathrm{U} / \mathrm{g}$ and $8.60 \mathrm{mg} / \mathrm{g})$, and starch $(16.89 \mathrm{U} / \mathrm{g}$ and 8.56 $\mathrm{mg} / \mathrm{g}$ ) as depicted in Figure 6.

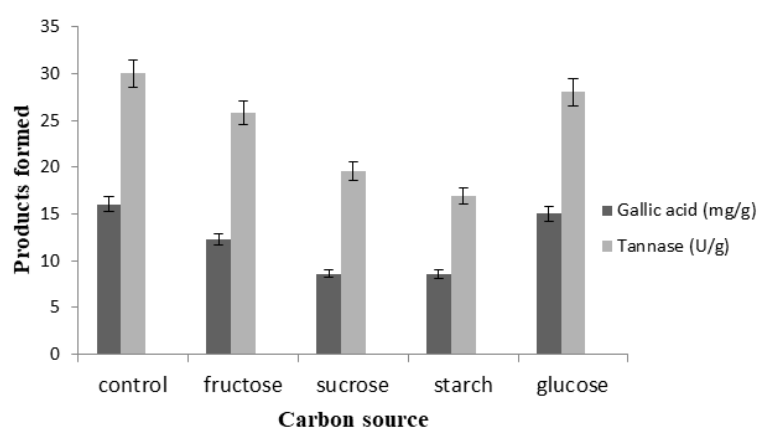

Figure 6: Production of gallic acid and tannase with addition of different carbon sources in fermentation media

\section{Nitrogen source}

Peptone, ammonium sulfate and urea (0.2\%) were used as the source of nitrogen. Tannase and gallic acid concentrations in control were $(30.01 \mathrm{U} / \mathrm{g})$ and $(16.00 \mathrm{mg} / \mathrm{g})$ respectively. Ammonium sulphate showed maximum tannase and gallic acid production $(34.40 \mathrm{U} / \mathrm{g})$ and $(16.66$ $\mathrm{mg} / \mathrm{g})$ followed by Urea $(26.54 \mathrm{U} / \mathrm{g})$ and $(11.06$ $\mathrm{mg} / \mathrm{g})$, peptone $(21.06 \mathrm{U} / \mathrm{g})$ and $(10.03 \mathrm{mg} / \mathrm{g})$, and yeast extract $(19.87 \mathrm{U} / \mathrm{g})$ and $(8.90 \mathrm{mg} / \mathrm{g})$ as shown in Figure 7.

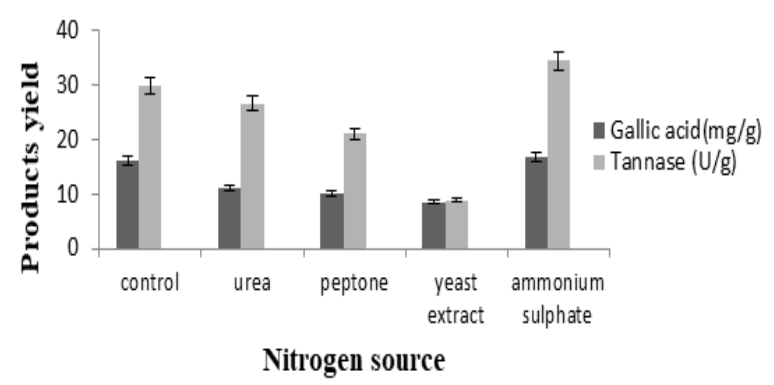

Figure 7: Production of gallic acid and tannase with addition of different nitrogen sources in fermentation media

\section{FTIR Spectra and HPLC Analysis}

The FTIR spectrum of fermented material showed similar bands like that of standard gallic acid which indicated the presence of gallic acid in sample (Figure 8). The quantitative estimation was conducted by HPLC method. By comparing the peak areas of sample with standard gallic acid solution of same concentration, purity of gallic acid produced was found to be $98.5 \%$ (Figure 9).

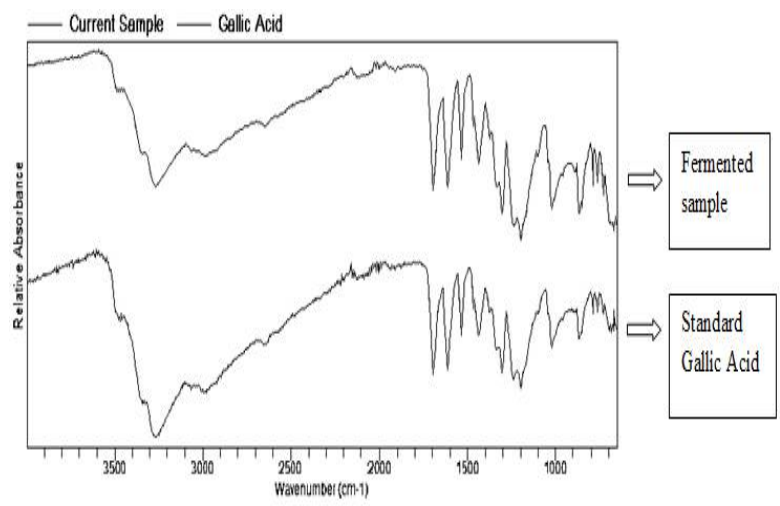

Figure 8: FTIR spectra of fermented sample and standard gallic acid

\section{DISCUSSION}

The present study was focused on testing the feasibility of utilization of different tannin containing fruits seeds for producing gallic acid and tannase by fungal isolate. Up till now, there is no report in literature for the production of gallic acid and tannase by using these specific substrates with fermenting strain $A$. oryzae through solid state fermentation.

In this study, tannin content of different substrates i.e. apple, tamarind, black plum, guava and watermelon seeds was estimated according to protein precipitation method by using bovine serum albumin (BSA) as standard protein [9]. Among them black plum seeds 
showed highest quantity of tannins $(191.25 \mathrm{mg} / \mathrm{g}$ dry seeds) which is near to the tannin content of jamun seeds reported in literature $(188.5 \mathrm{mg} / \mathrm{g})$ [16].
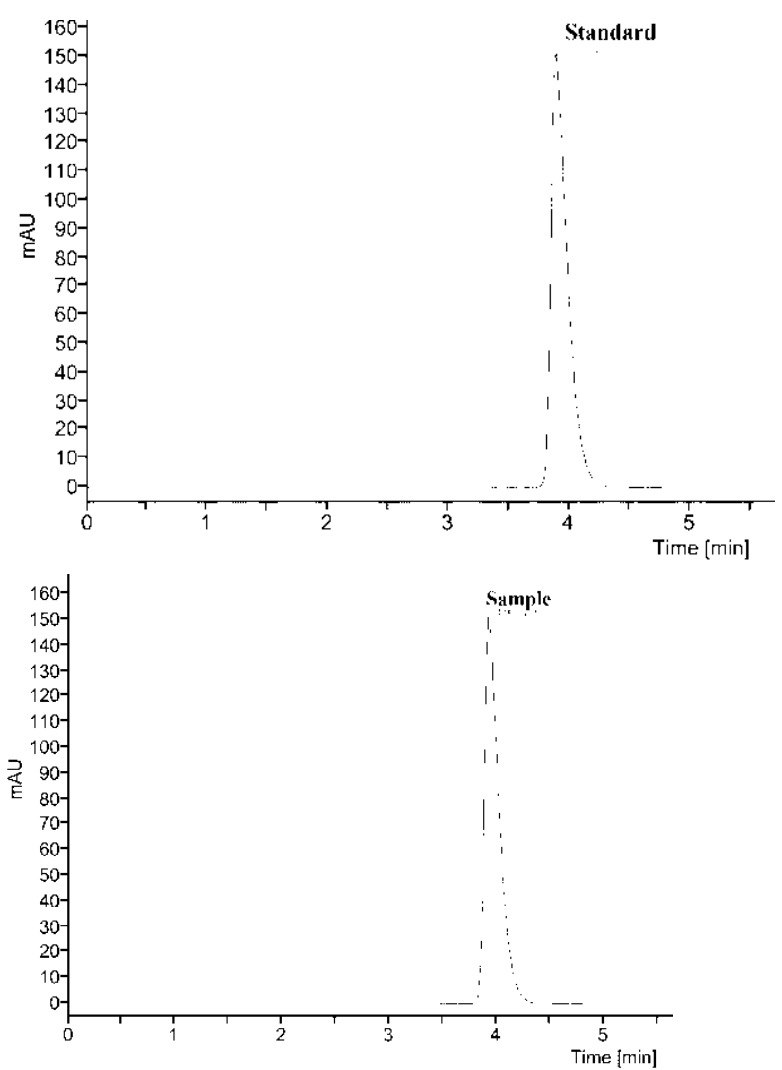

Figure 9: HPLC chromatograms of gallic acid standard (top) and fermented sample (bottom)

In present study, the black plum seeds were found to be the best among the five tannin containing substrates as they produced highest amount of gallic acid and tannase. Consequently, this substrate was used in further analysis for optimization of different parameters to achieve higher yield of gallic acid and tannase. Nandini et al [7], tested the utilization of various food and agriculture residues to obtain best yield of gallic acid and tannase like pomegranate peel, tamarind seed powder, banana peel, coconut coir, corn husk, jamun leaves powder, keekar leaves powder and spent tea powder by Aspergillus strain. These substrates were used separately as well as in the combination ratio of 1:1. Among the combination of substrates tested, pomegranate peel and spent tea in the ratio 1:1 was reported to produce highest yield of gallic acid $(5.32 \mathrm{mg} / \mathrm{g})$ and tannase $(19.21 \mathrm{U} / \mathrm{g})$. It was observed that increase in the substrate concentration above the optimum level resulted in decreased yield of both the products i.e. tannase and gallic acid. The reason may be that the membrane proteins of the microorganism make complex with tannic acid at its high concentration which ceases the fungal growth and hence tannase production [17]. In present study, at Substrate : water ratio of $1: 3$, the best yields of gallic acid $(14.43 \mathrm{mg} / \mathrm{g})$ as well as that of tannase $(23.44 \mathrm{U} / \mathrm{g})$ were obtained and above this ratio production of desired products was decreased. The reason might be that the supply of oxygen decreases by increasing the moisture level, resulting in lower enzyme production. Shanmugapriya et al [10] stated that the maximum tannase production from $A$. niger $(30.05 \mathrm{U} / \mathrm{mL})$ and $A$. flavus $(23.43 \mathrm{U} / \mathrm{mL})$ were obtained by fermentation of $3 \%$ concentration of Syzygium cumini seed powder.

At the incubation time of $96 \mathrm{~h}$, statistically significant $(p<0.05)$ and high yields of gallic acid $(15.01 \mathrm{mg} / \mathrm{g})$ and tannase $(26.40 \mathrm{U} / \mathrm{g})$ were detected as evaluated by one-way ANOVA. At $120 \mathrm{~h}$ of incubation period, there was a decrease in production that could be because of the formation of some metabolites which are toxic to the growth of microorganism. Similar results were reported in a previous study that highest yields of gallic acid $(0.653 \mathrm{mg} / \mathrm{g})$ and tannase (152.06 U/g) were obtained by Penicillium atramentosum KM after incubation period of 96 hours of jamun leaves [4]. The previous study, however, reported contrasting results as the maximum yield of gallic acid was observed after $48 \mathrm{~h}$ under solid state fermentation by using $A$. oryzae and myrobalan as tannin source where enzyme activity was $15.27 \mathrm{U} / \mathrm{mL}$ at $30^{\circ} \mathrm{C}$ [18].

At $\mathrm{pH} 5.5$, the highest production of gallic acid $(16.00 \mathrm{mg} / \mathrm{g})$ and enzyme tannase $(30.01 \mathrm{U} / \mathrm{g})$ and was achieved because $A$. oryzae prefers an acidic $\mathrm{pH}$ for growth and production. With the increase of $\mathrm{pH}$ level, the production of the enzyme started to decrease. The optimum $\mathrm{pH}$ of 5.5 was also reported in another study for the production of tannase by using $A$. niger ATCC 16620 [13]. However, the results of another experiment differed from the present data as the optimum $\mathrm{pH}$ for gallic acid and tannase production was found to be 6.0 by using both $A$. niger and $A$. flavus on jamun seeds through solid state fermentation [10].

Maximum production of gallic acid $(16.00 \mathrm{mg} / \mathrm{g})$ and tannase $(30.01 \mathrm{U} / \mathrm{g})$ was observed at the incubation temperature of $30{ }^{\circ} \mathrm{C}$. However, the production decreased when the temperature was above $30{ }^{\circ} \mathrm{C}$. The results are in line with Kumar et al [12], who reported the maximum yield of gallic acid $(0.534 \mathrm{mg} / \mathrm{g})$ and tannase $(69 \mathrm{U} / \mathrm{g})$ with jamun leaves at $30^{\circ} \mathrm{C}$ by using $A$. ruber under solid state fermentation. Shanmugapriya et al [10], also reported $30{ }^{\circ} \mathrm{C}$ as the optimum temperature for tannase production from 
Syzygium cumini seeds using $A$. niger (30.0 $\mathrm{U} / \mathrm{mL}$ ) and $A$. flavus $(25.42 \mathrm{U} / \mathrm{mL})$.

There was a decrease in gallic acid $(15.00 \mathrm{mg} / \mathrm{g})$ and enzyme $(28.00 \mathrm{U} / \mathrm{g})$ yield by addition of carbon source. It might be due to that the nutrient media already has enough carbon content needed for growth of fungus and enzyme production. Similar results were obtained by Sabu et al [13], as decrease in tannase activity was observed by adding glucose as source of carbon to fermentation media containing palm kernel cake and tamarind seed powder as substrate [13].

Among the different nitrogen sources tested, addition of ammonium sulphate to fermentation media resulted in enhanced yield of an enzyme $(34.40 \mathrm{U} / \mathrm{g})$ and gallic acid (16.66 mg/g). Shanmugapriya et al [10], reported ammonium nitrate to be the best nitrogen source for induction of tannase production by fungal isolates $A$. niger $(30.05 \pm 1.32 \mathrm{U} / \mathrm{mL})$ and $A$. flavas $(23.43 \pm 1.43 \mathrm{U} / \mathrm{mL})$.

\section{CONCLUSION}

For the first time, the development and optimization of a solid-state fermentation technique for tannase and gallic acid production using black plum seeds as a fruit-based residue by $A$. oryzae strain has been achieved. The optimized conditions were 1:3 substrate water ratio, $96 \mathrm{~h}$ incubation time, $30{ }^{\circ} \mathrm{C}$ incubation temperature, fermentation media $\mathrm{pH}$ of 5.5 , and $0.2 \%$ ammonium sulphate as nitrogen source. The pre-optimized conditions can be explored on pilot scale to meet the growing industrial demands of gallic acid. The adoption of this technique will not only help to solve the problem of waste disposal but will also result in enhanced production of the commercially significant products.

\section{DECLARATIONS}

\section{Acknowledgement}

The authors would like to thank the University of Veterinary and Animal Science Lahore for providing the facilities to perform the experimental procedures and to Miss AMNAH MOGHEES, Institute of Communication and Cultural Studies, University of Management and Technology, Lahore Pakistan for English editing.

\section{Conflict of interest}

No conflict of interest is associated with this work.

\section{Contribution of authors}

We declare that this work was done by the authors named in this article and all liabilities pertaining to claims relating to the content of this article will be borne by the authors. Ms Rida Arshad, Dr Ayesha Mohyuddin, Dr Shagufta Saeed, and Mr Abrar UI Hassan conceived and designed the study. Ms Rida Arshad collected and analysed the data and wrote the manuscript. Dr. Shagufta Saeed and Dr. Ayesha Mohyuddin assisted in analysing and writing of the manuscript. All authors have read and approved the manuscript for publication.

\section{Open Access}

This is an Open Access article that uses a funding model which does not charge readers or their institutions for access and distributed under the terms of the Creative Commons Attribution License (http://creativecommons.org/licenses/by/ 4.0) and the Budapest Open Access Initiative (http://www.budapestopenaccessinitiative.org/rea d), which permit unrestricted use, distribution, and reproduction in any medium, provided the original work is properly credited.

\section{REFERENCES}

1. Paranthaman $R$, Vidyalakshmi $R$, Murugesh $S$, Singaravadivel $K$. Accelerated bioconversion of agricultural by-products by supplementation of tannic acid in tannase production by Aspergillus Oryzae. Global J Biotechnol Biochem 2009; 4: 19-24.

2. Sivashanmugam $K$, Jayaraman $G$. Production and partial purification of extracellular tannase by Klebsiella pneumonia MTCC 7162 isolated from tannery effluent. Afr J Biotechnol 2011; 10: 1364-1374.

3. Thakur N, Nath A. Detection and production of Gallic acid from Novel Fungal strain penicilium crustosum AN 3 KJ820682. Curr Trend Biotechnol Pharm 2017; 11: 6066.

4. Selwal MK, Selwal LL. High level tannase production by penicillium atramentosum KM using agro residue under submerged fermentation. Ann Microbiol 2012; 62: 139148.

5. Goodarzian H, Ekrami E. Wool dying with extracted dye from pomegranate (punica grantum L) peel. World Appl Sci J 2010; 8: 1387-1389.

6. Lokeswari N, Raju KJ. Optimization of gallic acid production from terminalia chebula by Aspergillus niger. J Chem 2007; 4: 287-293.

7. Arunkumar S, llango K, Manikandan R, Ramalakshmi N. Synthesis and anti- inflammatory activity of some novel pyrazole derivatives of gallic acid. J Chem 2009; 6: S123-S128. 
8. Nandini KE, Gaur A, Sundry K. The suitability of natural tannins from foods and agriculture residue for producing industrially important tannase and gallic acid through microbial fermentation. Int J Agric Food Sci Technol 2013; 4: 999-1010.

9. Hagerman AE, Butler LG. Protein precipitation method for the quantitative determination of tannins. $J$ Agric Food Chem 1978; 26: 809-812.

10. Shanmugapriya N, Ramganesh S, Labhane $N$. Production, purification and characterization of tannase from Native Aspergillus Sp. using Syzygium Cumini (L) skeels (Eugenia jambolana) seed powder. Gold Res Thoughts 2014; 3: 1-12.

11. El-Fouly M, El-Awamry Z, Shahin AA, El-Bialy HA, Naeem E, El-Saeed GE. Gallic acid formation from gallotannins rich agriculture waste using Aspergilius Niger AMUC 4301 or its tannase enzyme. Arab J Nucl Sci Appl 2012; 45: 489-496.

12. Kumar R, Sharma J, Singh R. Production of tannase from Aspergillus ruber under solid-state fermentation using jamun (Syzygium cumini) leaves. Microbiol Res 2007; 162: $384-390$
13. Sabu A, Pandey A, Daud MJ, Szakacs G. Tamarind seed powder and palm kernel cake: two novel agro residues for the production of tannase under solid state fermentation by Aspergillus niger ATCC 16620. Bioresour technol 2005; 96: 1223-1228.

14. Sharma S, Bhat T, Dqwara R. A spectrophotometric method for assay of tannase using rhodanine. Anal Biochem 2000; 279: 85-89.

15. Entessar HA, Al-Mosawe AS, Al- Saadi I. The extraction and purification of gallic acid from the pomegranate rind. Al- Mustansiriyah J Sci 2012; 23: 53-60.

16. Balyan U, Sarkar B. Aqueous extraction kinetics of phenolic compound from jamun (syzygiumcumini) seeds. Int $J$ food prop 2017; 20: 372-389.

17. Banarjee R, Mondal KC, Pati BR. Production and characterization of extracellular and intracellular tannase from newly isolated Aspergillus aculeatus DBF 9. J Basic microbiol 2001; 41: 313-318.

18. Hota SK, Dutta JR, Banerjee R. Immobilization of tannase from Rhizopus oryzae and its efficiency to produce gallic acid from tannin rich agro-residues. Indian J Biotechnol 2007; 6: 200-204. 